\title{
HOW MUCH DOES LAW MATTER? \\ LABOR LAW, COMPETITION, AND WATERFRONT LABOR RELATIONS IN ROTTERDAM AND U.S. PORTS
}

\author{
ROBERT A. KAGAN
}

\begin{abstract}
In an increasingly competitive world marketplace, can cross-national variations in law-in this case, in labor law-produce markedly different economic outcomes? In both The Netherlands and the United States, law has helped rationalize the hiring of port labor and provide dockworkers greater security. However, American longshoremen have captured a larger share of the productivity gains flowing from the mechanization of cargo handling than have Dutch dockworkers. Because of constraints imposed by American longshore unions, container terminals in Rotterdam are more efficient and less costly to users. These differences can in part be explained by American labor law, which encourages a more adversarial, self-seeking union posture than does the labor law structure in The Netherlands. Probably more important, however, are economic factors, which expose Dutch dockworkers (but not West Coast longshoremen) to competition from ports in other nations. Similarly, international competition, intensified by the technological revolution in transportation, seems likely to impel cross-national convergence in many spheres, leveling differences in law and in legally influenced outcomes.
\end{abstract}

\section{DO CROSS-NATIONAL DIFFERENCES IN LAW MATTER?}

Modern legal systems are shaped by a basic political struggle. One side wants government to encourage economic efficiency and growth through economic incentives and free markets. The other demands more governmental regulation of (or compensation for) the economic losses, inequalities, environmental hazards, and social disruptions that flow from what Schumpeter (1942) called the "creative destruction" of capitalism.

In this political battle, law is used as both weapon and shield. Proponents of efficiency demand legal systems that protect prop-

The Netherlands Institute for Advanced Study provided support for research on which this paper is based. Additional support has been provided by the Institute for Governmental Studies and the Center for the Study of Law and Society, University of California, Berkeley, as well as the Center for Advanced Study in Behavioral Sciences, Stanford, California. Thanks are due Hendrik De Ru, Lloyd Ulman, Earl Westfall, Eric Nijhof, Harold Wilensky, Henry Farber, Joel Rogers, and Nelson Polsby for their helpful comments on earlier drafts, to Kurt DeBelder for translating Dutch sources, and to Anthony Brantenaar and Diana Watts for helping to arrange interviews in Rotterdam.

LAW \& SOCIETY REVIEW, Volume 24, Number 1 (1990) 
erty rights, enforce contracts, prosecute fraud, prevent cartels, and limit tax and regulatory obligations that might stifle entrepreneurial activity. They invoke legal traditions to resist incursions on economic liberties and the autonomy of private enterprise. Proponents of security, on the other hand, demand legal regulation of pollution, physical hazards, and exploitative employment practices, along with laws that provide subsidies or protections for workers, farmers, and industries whose livelihoods are threatened by competition. They invoke a newer legal rhetoric of human rights, equality, and social justice to extend welfare and regulatory laws.

If law is an important medium for the political struggle over economic and social policy, legal traditions in each nation may have an independent effect on the way in which the contest between efficiency and security is played out. In the United States, for example, a rather distinctive "legal style" has emerged (Kagan, 1988). Whether regulating school principals or polluters, police or pesticides, the United States tends to differ from other polities: generally speaking, it uses more tightly worded and detailed legal rules; more open, adversarial, lawyer-dominated, and costly rulemaking and adjudicatory procedures; more severe monetary penalties. American judges more often scrutinize and overrule the decisions of governmental and business entities. There is more political conflict about the legitimacy of existing laws, procedures, and judicial doctrines. ${ }^{1}$ To be sure, informal, negotiated settlements statistically outnumber formal, adversarial actions in American legal and regulatory processes (Galanter, 1983). But they are deeply affected (or distorted) by the bargaining endowments (Mnookin and Kornhauser, 1979) provided by the formal legal system-a system that from a comparative, macroscopic standpoint seems distinctively legalistic, adversarial, and contentious.

Labor relations-the focus of this paper-are no exception. Flanagan (1987: 3) recently observed:

1 For some illustrative comparative studies, see Badaracco (1985) on occupational health regulation in German, France, England, Japan and the United States; Bayley (1976) on regulation of police in Japan and the United States; Braithwaite (1985) on regulation of coal mine safety in several countries; Day and Klein (1987) on nursing home regulation in Great Britain and United States; Brickman et al. (1985) and Jasanoff (1986) on regulation of carcinogens in several countries; Kelman (1981) on occupational safety regulation in Sweden and the United States; Kirp (1979) on racial desegregation in British and American schools; Kirp (1982) on regulation of education for handicapped children in the United Kingdom and the United States; Langbein (1985) on civil litigation methods in West Germany and the United States; Lundqvist (1980) on air pollution regulation in Sweden and the United States; Quam et al. (1987) on medical malpractice litigation in Great Britain and the United States; Vogel (1986) on environmental regulation in Great Britain and the United States.

Of course, national legal styles are not monolithic. They vary within nations and even within branches of the same legal institution. With respect to regulatory enforcement style, see Kagan (1989). 
Under the NLRA [National Labor Relations Act], union organizing is to an important extent a legal process with an intricate set of rules (established over the years by the NLRB) governing almost every aspect of conduct by unions and employers as they seek to influence how workers vote on the question of unionization .... The result has been a level of regulatory activity and litigiousness in labor relations that is without parallel in the rest of the world.

Comparing the United States to European nations, Bok concluded that American law creates a more adversarial relationship between labor and management. Unions and management, he noted, each view current law as "a body of rules which one side has succeeded in enacting at the expense of the other," to be resisted and exploited for immediate advantage (Bok, 1971: 1449).

But how much do such differences in national "styles of law" really matter? A possible answer is "Less than one might think." Comparative studies often conclude that although the American regulatory style is more legalistic and adversarial than England's or Sweden's, the regulatory standards end up about the same (Badaracco, 1985; Kelman, 1981; Vogel, 1986). After all, one might argue, modern, industrialized democracies share both scientific information about risks and basic conceptions of justice; thus the goals of regulatory controls are likely to be roughly similar. At the same time, in democratic industrialized nations, the institutions subject to legal control, public or private, share basic economic imperatives; if they are to perform their social functions, legal controls must be compatible with those imperatives. Hence the "null hypothesis": regardless of national differences in legal methods, demands for security and for economic competitiveness will produce at least rough convergence in outcomes. If convergence is lacking, it should be attributable to cross-national differences in economic resources and constraints.

Logically, however, the "competitive convergence" hypothesis would hold only where markets are competitive and it is relatively easy to amend, renegotiate, or evade economically inefficient legal measures. In practice, markets, especially international markets, are riddled with both inherent and politically generated imperfections. Many laws and regulations are explicitly designed to limit competition, domestic and international. The political forces that put those laws into place fiercely resist their reformulation. In opposition to the competitive convergence hypothesis, therefore, one might advance the "law matters" hypothesis: when one nation, through law, imposes a higher implicit "tax" on an activity by subjecting it to costly obligations, liability rules, adjudicatory mechanisms, and regulatory standards, that activity will be carried out differently than in countries where the law establishes weaker constraints and or a different set of incentives. In sum, law will have distinctive distributional and efficiency-related consequences. 
Sociolegal scholarship, by and large, provides little systematic guidance concerning the relative power of the law matters versus the competitive convergence hypothesis. One way of pursuing the question is to undertake case studies of similar social processes, or legal responses to similar social problems, in different nations. This article compares the legal response of two nations, the United States and The Netherlands, to the conflict that historically characterized labor relations in major commercial seaports. It also compares how Rotterdam and American West Coast ports adapted to dramatic economic and technological changes in seaport operations. The struggle to bring order to the port in these two nations, it will be shown, produced somewhat different social and economic outcomes, partly due to variations in law, but also, and probably more importantly, due to differences in economic and geographical factors. ${ }^{2}$

\section{DISORDER IN THE PORT}

Through the eighteenth, nineteenth, and much of the twentieth centuries, dockworkers in Rotterdam and San Francisco, London and New York, Shanghai and Bombay, had similar complaints about their lot-intermittent work and earnings, punishing productivity quotas, high injury rates, and an often corrupt process of work assignment (Miller, 1969). These unhappy conditions were rooted in the casualism that characterized the competitive longshore labor market. Typically, many small stevedoring firms-enterprises that loaded and unloaded ships-were scattered among the many docks in a large harbor. ${ }^{3}$ On a given day, a single steve-

2 In addition to usual academic and governmental publications, the research underlying this account is based on unstructured interviews with scores of officials in port authorities, shipping and stevedoring companies, maritime consulting firms, and labor unions in the United States, The Netherlands, and Hong Kong, as well as regular reading of Pacific Shipper, Containerisation International, and several other trade publications.

3 In some times and places, the term stevedore has been applied to the laborers who do the manual work of loading and unloading ships. In this article, however, following dominant contemporary American usage, stevedore refers to the firm or entrepreneur who contracts to provide labor for cargo handling, that is, the employer of dockworkers, or, as they are often called in the United States, longshoremen-a derivation from the British "alongshoreman." In the United States, "longshoreman" came to refer both to the men who handle cargo "along shore" on the docks and to those who work on board ship, operating shipboard cranes or stowing cargo in the hold.

Historically, the stevedoring company, which provides labor to shipping companies (ship operators), has been distinct from the terminal operator-the company that operates the physical facility (docks, storage areas, cranes, forklifts) at which ships are loaded. (The port authority, the overall landlord, typically leases terminals to competing terminal operators.) Today, however, the terminal operator often also provides stevedoring services, and I use the terms terminal operator and stevedore interchangeably. Moreover, large shipping companies or consortia of shipping companies nowadays often form their own stevedoring/terminal operator subsidiaries. In referring to dockside employers, therefore, I generally mean a combination of stevedores, terminal operators, and shipping companies. 
doring firm might work several ships or none at all, for the volume of shipping varied by weather conditions and by fluctuations in trade volume. No single firm could afford to provide regular employment to dockworkers through foul weather and fair. Yet when ships were in port, shipping companies were willing to pay well for rapid loading and unloading. Thus hourly wages for dockworkers typically were comparatively high, which helped to attract sufficient numbers of workers to the port to handle peak demands (Phillips and Whiteside, 1985: 6). Each morning, clumps of workers assembled at the different piers in hopes of being hired for a few days of intensive, remunerative work. But overall, the available dock labor force tended to be larger than necessary to meet peak demand, and much larger than average demand. Hence chronic underemployment was pervasive. Most dockworkers' average annual earnings were low, compared to regularly employed laborers (Hartman, 1969: 25-26; Hobsbawm, 1964: 209; Lis, 1986: 36; Cooper, 1987: 27). The intermittent nature of employment drove many men into debt and drink.

Once employed, dockworkers stayed on an already onerous job to the point of exhaustion, knowing that employers, pushed by shipping companies to get the vessel loaded and under way as quickly as possible, were ready to replace a resting worker with a fresh man from the waiting crowd. Disabling injuries were very frequent. 4 With a surplus of hungry men to choose from at the morning "shape up," the hiring boss often was a target for bribery. Conversely, he commonly extorted kickbacks from men he agreed to take on. In Shanghai, dockworkers were expected to make large donations to the stevedore who hired them (Ch'en Kang, 1977). In New York, and probably in other ports where it was less well documented, pilfered cargo created a currency for such payments. In many ports, the lucrative possibilities for controlling access to jobs led organized criminal elements to seize control of stevedoring firms or dockworker unions and to use ungentle methods to retain that power (on New York, see Bell, 1964; on Melbourne, see Morris, 1983). Similarly, ethnic and racial groups often clashed in the struggle to gain priority at particular piers (on New York, see Kimeldorf, 1988; on New Orleans, Northrup, 1942).

For dockworkers, the logical remedy for the insecurity and ills of casual employment was to create a competition-restricting labor cartel-that is, to establish an exclusionary closed shop, whether by coercion (as in the case of tough gangs of ethnically bonded workers), or by agreement with employers (presumably via strike threats), or by law. Stevedores and marine terminal operators

4 As late as 1942, the U.S. Department of Labor reported that dockwork was one of the most dangerous job categories. Longshoremen sustained 138 disabling injuries per million employment hours (Schneider and Siegel, 1956). As I calculate it, this implies that one in seven dockworkers would incur a serious injury every six or seven months, on the average. 
would be obliged to hire only cartel members-a restricted set of "regular" dockworkers. The cartel might insist on higher wages and nondiscriminatory job assignment among cartel members. The cartel might also insist on smaller loads, shorter work shifts, mandatory task specialization, and larger work gangs-all of which would spread existing work among all cartel members. Ideally, the cartel would also achieve remuneration for its members even on days when there were no ships to be worked.

The vital position of dock labor in the flow of commerce brought such goals within the range of possibility. If dockworkers could organize labor unions and engage in effective strikes or slowdowns, their power to cork the bottleneck of trade would put stevedoring firms under great pressure from shippers and consignees to grant any concessions necessary to remove the stopper. In fact, dockworkers, exposed to ideas from abroad, enjoying ample time to discuss their situation in waterfront saloons, were among the first workers to form unions. By the late nineteenth century, labor radicalism periodically erupted on the docks of San Francisco, London, and Rotterdam (Kimeldorf, 1988; Jensen, 1974). Specialized, skilled dockworkers, such as coal-heavers in Liverpool and the men who stowed cotton in New Orleans ships, had effective unions during the nineteenth century.

But unions enrolling the mass of dockworkers, who were easily replaceable by unskilled men, had less leverage. Large-scale dock strikes occurred with some frequency-in Rotterdam, for example, in 1889, 1896, 1900, 1905, 1907, 1911, 1917, and 1920 (Jensen, 1964; Nijhof and Schrage, 1988). American longshoremen spearheaded citywide general strikes in San Francisco in 1901 and 1934 and mounted numerous work stoppages in other West Coast ports in the 1890-1920 period. Employers, however, often imported strikebreakers to try to maintain the flow of goods through the ports. Violence typically ensued. Port-city governments and police departments often used force to protect the strikebreakers. Employer associations created blacklists, excluding former strikers and union members from employment. In most ports, before the 1940 s or 1950 s labor unions only intermittently exerted significant power, and casualism in hiring and deployment prevailed.

When dock unions did succeed in creating closed shops, disorder of another kind often ensued, as they used their power to frustrate the installation of labor-saving loading technologies, ${ }^{5}$ reduce the pace of work, implement makework rules, and demand extor-

5 In New Orleans, for example, cotton screwmen, skilled workers who used huge hand screws to pack cotton bales into ships, had two strong unions in the late nineteenth century, one black, one white. Around the time of World War I, a high-powered cotton press came into use, capable of stowing cotton much more rapidly and operable by unskilled workers. Nevertheless, the screwmen's unions forced waterfront employers to keep their members on the payroll and let them operate the new machines, but also to continue to pay them the preexisting high skilled-labor piece rates (Northrup, 1942). 
tionate wages. As employers resisted, strikes and slowdowns often erupted. In the latter half of the 1930s, the newly consolidated longshore union on the U.S. West Coast engaged in scores of "quickie strikes" every year, refusing to load or unload a particular ship until concessions were made. In the 1950s and 1960s, long dock strikes repeatedly tied up East and Gulf Coast ports until federal mediators pressured employers to make large concessions to unblock the gates of trade (Ball, 1966). Cross-national studies of interindustry propensity to strike placed dockworkers at the top (Kerr and Siegel, 1964).

\section{DECASUALIZATION: HIRING HALLS AND LABOR POOLS}

By the 1960 s or 1970 s, most major ports had institutionalized, by law or by governmentally supported collective bargaining, organized systems for limiting competition in the dock labor market and for increasing the income of a limited subset of dockworkers. The schemes generally involved three elements:

1. Designation of an "in-group" of officially registered (in effect, licensed) dockworkers-and sometimes a second designated group with lower preference in hiring.

2. Registered workers who were not permanently employed at particular stevedoring enterprises were hired through a central pool or hiring hall, which stevedores were obligated to use for their primary source of casual labor.

3. A system of minimum pay guarantees or unemployment benefits for registered dockworkers who were left idle by a shortage of ships to be worked during a particular day, week or month.

As a result of these plans, dockwork unions generally were strengthened. Workers now are fewer in number but enjoy greater stability of earnings and more control over on-the-job work rules.

Decasualization schemes differ in two principal ways: (a) the relative power of labor unions in controlling work assignments, and (b) the sources and level of income support for idled registered workers. The role of government and its labor laws seems important in this regard, but so are a series of economic, cultural, and geographic factors, as the following accounts of decasualization in U.S. West Coast ports and Rotterdam indicate.

\section{A. American West Coast Ports}

Early in the twentieth century, West Coast dockworkers had a tradition of radicalism. Many were "Wobblies," members of the International Workers of the World (IWW), sharing its dream of "one big union" encompassing all workers (Kimeldorf, 1988). Their periodic strikes induced waterfront employers in some ports 
to take organized countermeasures. In Seattle, Portland, and Los Angeles, after finally breaking a seventy-four-day 1916 dockstrike by importing strikebreakers, local associations of shipping companies and terminal operators established their own hiring halls. These stabilized employment for an inner core of longshoremen who were admitted into "company unions," while excluding members of the IWW, the International Longshoremen's Association (ILA), and Communist-front unions. In the large port of San Francisco, employers were more fragmented and workers more resistant to company-run hiring halls; the daily dockside shape up, as well as a punishing work pace, prevailed (Larrowe, 1955, 1972). During the 1920s, shipping companies, aided by improvements in rail and truck transport, could circumvent a strike in one port by diverting ships to another. Dockworkers came to believe that only a single, coastwide union, acting in concert in all ports, could improve their lot. In the $1930 \mathrm{~s}$, the federal government helped them achieve that goal.

In 1933 the New Deal Congress enacted the National Industrial Recovery Act (NIRA). Workers were guaranteed "the right to organize and bargain collectively through representatives of their own choosing." The NIRA also called for industry-formulated fair trade codes (no price cutting), administered by the National Recovery Administration (NRA) and for fair labor practice codes (basically, industrywide adherence to wages negotiated between organized labor and industry associations). The NRA, America's tentative step toward European-style corporatist government, soon became politically unpopular and in 1935 was ruled unconstitutional. ${ }^{6}$ Before that happened, however, the NRA gave a sharp boost to labor organizing throughout the nation. The ILA sought recognition as the representative for all West Coast longshoremen and demanded union-controlled hiring halls in each port (Larrowe, 1955: 96). Employer resistance led to an eighty-threeday strike in 1934, pitched street battles on the San Francisco waterfront between longshoremen and police called out to guard strikebreakers, and a general strike of all trades. Urged to help keep the ports operating, President Roosevelt appointed a board of mediators for the West Coast stevedoring industry. In the spirit of the NRA, it sought an "industry-wide solution," ultimately issuing an award calling for a coastwide agreement and hiring halls in

6 In Schechter Poultry v. United States, 295 U.S. 495 (1935), the U.S. Supreme Court held that the NIRA contravened the Constitution by delegating lawmaking power to industry trade associations, without significant legal guidelines for the administrative bodies assigned to supervise and enforce the regulations. Historians believe that even if the Court had not done so, Congress would have declined to renew the act (Hawley, 1966). After Schechter, the Congress passed the National Labor Relations Act (1935), which reasserted workers' rights to organize, bargain collectively, and strike. But unlike the NIRA, the $\mathbf{1 9 3 5}$ act did not provide for mandatory extension of labor-management agreements to all competing firms in an industry. 
each major port, jointly run by union and management; but the critically important hiring-hall dispatchers ${ }^{7}$ were to be selected by the ILA (later to reconstitute itself as the ILWU). Differences over work rules were to be settled by arbitration.

Suddenly, the West Coast longshoremen had their cartel: to this day, no stevedoring companies or marine terminals on the coast have circumvented the union-dominated hiring hall, unionwage settlements and arbitrated work rules. In the years after 1934, the union moved aggressively to assert control over registration of dockworkers, job assignments, discipline, and the pace of work, engaging in scores of localized "quickie strikes" and several lengthy coastwide work stoppages. As Freeman and Medoff (1984) have emphasized, labor unions display both a "monopoly face," using power to extract economic benefits for their members, and a "collective voice face," arguing against arbitrary employment practices and devising institutional mechanisms to prevent them. Thus the ILWU used its newfound power to enable longshoremen to resist brutal employers and dangerous, backbreaking work demands, and gave dockworkers more control over their own working lives. But in this case, increases in security also led to sharp decreases in efficiency.

By insisting that jobs be assigned to dockworkers on a rotating basis, so that workers could not report regularly to the same terminal, union work rules undermined employers' capacity to discipline unresponsive men and redirected the longshoreman's loyalty from any individual employer to the union and its hiring hall. Initially justifiable union work rules designed to improve safety (e.g., restrictions on the weight of sling-loads) gradually became mechanisms for featherbedding, creating makework tasks, extorting overtime pay, and blocking technological change. Productivity plummeted (Hartman, 1969).

Employers resisted every step. Hundreds of disputes were taken to arbitration. Employers pushed for the deportation of Australian-born ILWU leader Harry Bridges as a Communist party member or sympathizer (Kutler, 1982; Larrowe, 1972). ${ }^{8}$ But in 1948, after a long strike, a new management team took over a reconstituted coastwide waterfront employers organization, the Pacific Maritime Association, and adopted a stance of cooperation

7 In the hiring hall system, the dispatcher replaced the numerous stevedoring companies and their pier-based hiring bosses in selecting men to be assigned to available jobs each day. In principle, and to a large extent in practice, the ILWU hall operates according to an impartial rotation system. But dispatchers, through the exercise of discretionary judgments, can withhold workers (or the best workers) from employers who refuse to cooperate with union work preferences. And the dispatcher can subtly discriminate against dockworkers who don't support union policies.

8 In 1950, the Congress of Industrial Organizations (CIO) expelled the ILWU for "consistently" seeking, the CIO alleged, "the achievement of the policies of the Communist Party" as defined in Moscow (Larrowe, 1955: 134; see also Kimeldorf, 1988). 
with the ILWU (Kerr and Fisher, 1949). In return for a no-strike clause during labor contract periods, they basically gave in to union power over hiring and work assignment, and strikes have since been infrequent. By the late 1950s, motorized forklift trucks and conveyor systems (for bulk materials) made the union's restrictive work rules look increasingly indefensible, and coastal trade continued to slip away from shipping to trucks. The ILWU agreed to a basic exchange: elimination of inefficient, restrictive practices in return for greater job security and benefits. Under the 1960 Mechanization and Modernization (M \& M) Agreement, stevedores and shipping firms acquired the right to introduce new machinery, eliminate multiple handling, and reduce gang sizes. ${ }^{9}$ In return for rapid arbitration of grievances, longshoremen would continue to work pending a job dispute, while on-call arbitrators would drive at once to the dock.

Here was the major price: under the M \& M Agreement, employers agreed to maintain the full-employment pay level of registered longshoremen rendered redundant by the ILWU's relaxation of makework rules. Retirement benefits for longshoremen were increased dramatically. All this was to be financed by employer contributions of about $\$ 29$ million (or over $\$ 100$ million in 1988 dollars), to be raised by a charge to shipping lines for each ton of cargo (Ross, 1970; Fairley, 1979). In 1972, after the first coastwide strike in many years, the employers extended the weekly pay guarantee plan to longshoremen idled for a short time due to lack of work in their port in any particular week. Registered West Coast longshoremen had a guaranteed income for life, regardless of the economy's fortunes. ${ }^{10}$

\section{B. Rotterdam}

The Port of Rotterdam, at the mouth of the Rhine, today is the world's largest port. During the late nineteenth and early twentieth centuries, as the port grew rapidly, dock labor unrest exploded into numerous strikes. To The Netherlands, a small nation deeply dependent on trade, work stoppages in the harbor were especially troubling. In 1908 , the Rotterdam association of shipowners and stevedores (the SVZ), sought to stem labor radicalism by entering into a collective agreement with several dockworkers' unions. Henceforth, portwide agreement on wages-even if evaded

9 In the two years following the $M \& M$ agreement, productivity in West Coast ports (controlling for technology and type of cargo) increased by an estimated 30 percent (Hartman, 1969), which provides some indication of the earlier effect of ILWU job-protecting work rules.

10 As it turned out, Pacific Rim trade volume grew so rapidly in the 197090 period that dock work generally was plentiful. Although the number of registered workers declined somewhat, relatively few longshoremen were forced by lack of work into retirement. On the East Coast, where trade did not grow as rapidly, job losses from containerization were greater (see note 18 below). 
by some employers-was the norm for Rotterdam (Jensen 1964: 220-27). In 1917, the SVZ (following the example of harbor employer associations in Hamburg and Amsterdam) established a centralized hiring system, the Havens Arbeider's Reserve (HAR). It provided for registration of a maximum number of "regular" dockworkers who gathered at set times in a covered hall; there employers from all docks would come to select the workers they needed. By 1919, the HAR had become responsible for centralized payment of wages, payment of compensation to injured dockworkers (pursuant to a national law), and-in this regard going beyond the hiring hall system as first set up in U.S. West Coast ports in 1934-payment of minimal unemployment benefits to registered dockworkers who had not been selected for work over a six-day period (Nijhof, 1988). ${ }^{11}$

As in the United States, government action was critical to decasualization. In 1914, the Dutch government passed the Stevedore's Act, which banned child labor from the docks, limited hours of work, established safety rules, and prohibited hiring and payment of wages in saloons. The act also provided for a governmental labor inspector and, to assist him, a joint labor-management safety committee and a more general joint dock labor advisory committee. More importantly, as World War I reduced international trade and hence jobs in neutral Holland, the Dutch government created public employment exchanges and provided subsidies to voluntary systems of unemployment insurance based on contributions by union members and employers (Levenbach, 1964: 546). The SVZ's centralized registration scheme was created in response to a 1917 general strike demanding such unemployment benefits. (Centralized registration, it would seem, would enable employers to limit the number of dockworkers eligible for unemployment payments and give the SVZ control over the operation of the "employment exchange.")

In the next two decades, dock strikes in Rotterdam were infrequent by American and British standards, even though the Havens Arbeider's Reserve was created and run by employers. Rotterdam shipping and stevedoring firms (not the union) continued to exercise choice over which workers to select from the pool and over the number of workers admitted to the pool by registration. Because each employer chose a number of regular, permanent men, work remained irregular for a substantial number of more marginal dockworkers, and unemployment payments apparently were rather low. These features-low average earnings and

11 In practice, some registered dockworkers were employed permanently by particular stevedoring firms or worked for them rather regularly. The hiring hall could also be used by nonregistered workers seeking any dockwork that might remain after all registered dockworkers had been selected. These non-HAR workers were not covered by the unemployment payment scheme mentioned below. 
employer choice over whom to hire (with its potential for favoritism)-are precisely what West Coast dockworkers disliked about employer-controlled halls in Seattle and Los Angeles during the 1920 s, stimulating the ILA's ultimately effective demands for a union-controlled hiring hall which would assign men to jobs strictly by rotation. Why did this not occur in Rotterdam? Moreover, what distinguished the HAR from the ILWU-dominated hiring halls in the late 1930s, which produced decasualization but also continuing strikes and labor disputes?

The answer lies partly in social organization. Dutch employers' control over worker selection was partly attributable to the organizational weakness of Dutch dock labor, which was fragmented among a mainstream socialist union, a more radical union, a Catholic union, a Protestant union, and a larger group of nonmenbers. ${ }^{12}$ The U.S. West Coast dockworkers, in contrast, resentful of their fragmentation into port-specific company unions in the 1920s, coalesced into a single, coastwide union, ideologically driven and determined to act in concert (Kimeldorf, 1988). ${ }^{13}$ On the management side, waterfront employers were much more tightly organized in Rotterdam than in America, reflecting a nationwide movement in The Netherlands to establish employers' associations that could deal with labor in a concerted manner (Van Voorden, 1984). Linked by interlocking directorates, Dutch stevedores and shipping companies could ensure that most-although not allharbor employers would hire casual labor only through the SVZoperated pool, on common terms, thereby moderating competition. On the U.S. West Coast, employers-more numerous, independent, competitive, and geographically scattered-were unable to establish a viable coastwide organization until after the union's battle for a coastwide contract had essentially been won. ${ }^{14}$

12 In 1922, even after a strike was called, the SVZ refused to bargain with the main socialist dockworkers union, claiming it had come under radical, foreign influence. Members of the rival Catholic and Protestant dockworkers unions returned to work. Henceforth, dockworkers were divided (Jensen, 1964).

13 The importance of organizational unity is also suggested by labor's experience in other ports. On the U.S. East and Gulf Coasts, where the International Longshoremen's Association (ILA) was a loose association of separate, local unions-ethnically divided, often corrupt, often dominated by criminal organizations-decasualization did not occur until 1953, after a government investigation of labor corruption resulted in abolition of the shape up and creation of a registration scheme and hiring hall, operated under the aegis of the governmental port authority (Jensen, 1974; Kimeldorf, 1988). In Great Britain, where dockworkers, as other workers, were divided into scores of small craftspecific unions, decasualization did not occur until a Labour government established a national dock labor scheme by law in 1947, requiring registration of workers, rationalized job assignment, and unemployment benefits for idled workers (Phillips and Whiteside, 1985; Jensen, 1964).

14 In the large port of San Francisco, employers were unable to establish a common employer-dominated hiring system even in the 1920 s. Where employers were even less unified, as in the still larger ports of New York and London, decasualization did not occur until after World War II and then, as noted earlier, only as a result of governmental intervention. 
In accounting for the Rotterdam/U.S. West Coast differences, labor law may also have played some role. Dutch law, as noted, subsidized voluntary unemployment payment schemes, including one covering temporarily idled dockworkers. In the United States, in contrast, while the New Deal government in Washington helped the longshore union achieve coastwide power, it did not extend the (mandatory) unemployment insurance law (1935) to intermittently employed casual workers like longshoremen. Without such a governmentally subsidized program, the ILWU sought a guarantee of regular earnings by "job creation" strategies-demanding, and striking for, a slower work pace, larger gang sizes, makework rules, and elimination of "steady gangs" permanently employed by particular stevedoring firms. In Rotterdam, where the government-subsidized harbor-employer (SVZ) insurance plan helped provide some small cushion for dockworkers, the Dutch unions imposed certain restrictive practices, but much milder ones than those in San Francisco and Los Angeles, and Dutch unions did not halt the permanent employment of valued workers by particular companies.

Government policy and law definitely played a major role in Holland in the decade after World War II, when dockworkers in America and England exploited their power to bottle up commerce and thereby obtained large wage gains. Rotterdam dockworkers were restive, too, and engaged in strikes in 1945 and 1946. But during the postwar period, Rotterdam dockworkers' bargaining power was limited by a national legal regime designed to spur recovery from wartime devastation by encouraging investment and holding down wages. Dutch employers, on the docks as elsewhere, were forbidden to pay wages higher (or lower) than a "social minimum wage" (with various adjustments) set by the national government, reflecting mediated agreements among "peak associations" of industry and labor unions (Sturmthal, 1957). To prevent inflation, wage increases were limited to average productivity gains. In return, the government mandated statutory nonwage benefits, such as pension rights, paid vacations, and increased unemployment insurance (Pels, 1957: 112-14). In the 1960s and 1970s, governmental legal controls were relaxed, but they left an important legacy: a tradition of centralized bargaining on an industrywide basis by national trade union federations and employers associations. Union federations continued to push for roughly equal pay scales across industries.

As trade expanded, both harbor employers and dockworkers chafed under the centralized bargaining system. Employers couldn't get enough workers at the low, controlled wage and sought to provide other inducements: more regular employment and pay guarantees, education programs for dockworkers, and social programs for families (Nijhoff, 1988). After resorting to wildcat strikes, dockworkers in 1955 won an increase of the pay guar- 
antee for temporarily idle union members-to 80 percent of normal wages. By law, half of that amount was to be financed by a tax on employers, the rest by the national government's unemployment fund. (In the United States, in contrast, the pay guarantee for idle dockworkers is financed entirely by stevedoring and shipping firms-and their customers-as a result of the basic productivity-for-security bargain the ILWU made in 1948 and 1960. In Antwerp, the Belgian government pays 70 percent of the unemployment payments received by idle workers, compared to the Dutch government's 50 percent.)

In 1963 and 1970, wildcat strikes in Rotterdam yielded gains in relative pay for dockworkers and greater union control in the operation of the central hiring pool, so that workers had more choice and employers less in determining job assignments. Nevertheless, in contrast to Los Angeles, Seattle, and San Francisco Bay, Rotterdam stevedoring terminals remained free to offer priority to steady gangs, who reported directly each day to the same employer's terminal, much as a factory worker might. By the mid1960 s, employers drew on the pool for only 20 to 30 percent of their labor needs, on the average. ${ }^{15}$ By the $1980 \mathrm{~s}$, that figure was far lower. Dutch dockworkers, like Americans, had virtually guaranteed incomes, even when trade was slack, but had very different relationships with their employers.

\section{ADAPTING TO THE TECHNOLOGICAL REVOLUTION}

In the past two decades, market-driven technological changes have wrought major changes in port operations and international trade. Among the most striking developments have been the containerization of general cargo; faster automatic loading and unloading systems for bulk cargos (oil, coal, grain); much larger, specialized ships for containers, various bulk commodities, and motor vehicles; instantaneous electronic interchange of shipping documents and information; and "intermodalism"-systems for rapidly transferring containers from ships to specially designed trains, trucks, and barges for inland destinations (and vice versa), all under contract with a single transportation company. These technologies have intensified competition among nations by vastly re-

15 In San Francisco/Oakland, every longshoreman must first report to the hiring hall and is assigned essentially at random to different employers. The ILWU has relented in part with respect to operators of huge, expensive container cranes, agreeing that they should be allowed to work as "steadymen" at particular terminals where they can become familiar with specific cranes and procedures. Nevertheless, although the crane operators usually live on the Oakland side of the Bay, near the container terminals, the union insists that they must report first to a hiring hall in San Francisco. This results in a fictional arrangement whereby the crane operators go directly from their East Bay homes to the Port of Oakland but are paid for transit time between the San Francisco hiring hall and Oakland. On "steadyman" crane operators in Los Angeles, see Finlay, 1988. 
ducing international shipment costs, and intensified competition among ports by diminishing their natural geographic advantage in serving nearby hinterlands. The huge capital costs and tight schedules associated with these technologies also have increased pressures on stevedores and shipping companies to avoid work stoppages. At the same time, the enormous productivity increases have provided shipping companies and marine terminal operators with the financial means to avoid work stoppages. By granting dockworkers large increases in pay and job security, the dockside employers (in Holland, with some support from government) have purchased order from the dockworkers unions, along with the right to deploy workers more efficiently.

Holland and the United States have differed, however, with respect to the distribution of the productivity gains generated by the new technologies. In the United States, labor unions captured a proportionately larger share. Moreover, American longshoremen have also retained hiring practices and work rules that make American stevedoring operations less efficient and more costly than comparable operations in Rotterdam. These differences are attributable partly to the different economic pressures that flow from the divergent geopolitical configurations of The Netherlands and the United States. But they also flow from differences in labor law in the two nations.

\section{A. Containerization}

It will be helpful to concentrate on one aspect of the technological revolution in transportation-containerization and intermodal transport of general cargo, introduced at the end of the 1960 s in West Coast ports and in Rotterdam. Today, general cargo typically is stowed at the shipper's loading dock in a sealed fortyfoot rectangular steel box (essentially a truck trailer detachable from its chassis), driven to the dock, loaded onto a ship for ocean transit, unloaded overseas, and transported to the consignee by train or truck-without being opened, without the multiple handling and repacking that historically led to high labor costs, damage rates, and pilferage. ${ }^{16}$ At the dock, a giant, wheeled gantry

16 Before containerization, general ("breakbulk") cargo generally was shipped in small packages or on wooden pallets, moved by truck to dockside warehouses, then by forklift truck to the dock. There prestacked pallets, or irregular pallet loads assembled and secured by dockworkers, were lifted by shipborne cranes into the hold, where they were individually stowed. Between the shipper's loading dock and the ultimate destination overseas, the goods had to be handled and repacked and secured many times. Loading and unloading ships was slow: a typical cargo ship spent far more time in port, piling up docking fees and crew wages was well as stevedoring costs, than it did in transit. For shippers of goods, port costs accounted for about 40 percent of all shipping costs (Campbell, 1986: 5). (Today that figure is about 16 percent for containerized cargo. See note 21 below.) Losses due to pilferage and damage in handling were large, often 5-10 percent and in some cases 24 percent of the value of cargo (Campbell, 1986). (According to one shipping line official, con- 
crane loads another 20,000-pound container onto the ship every three minutes-a fraction of the time it took for an equivalent weight laboriously packed onto wooden pallets. Gangs of dockworkers no longer are needed in the hold to stow the cargo. The containers are sealed and numbered at the factory or warehouse gate, eliminating the need for labor-intensive dockside checking and counting of goods. Impervious to weather and difficult to steal, imported containers are stacked in yards near the dock like books in a Brobdignagian library, ready for rapid transfer to over-the-road trucks or railroad cars. In Rotterdam, containers are lifted directly from the ship onto large motorized barges that carry them up the Rhine to Germany, France, and Switzerland. Standard-sized containers have been built for chemicals and fluids (cylinders fitted into oblong frames) and for perishable fruits, meats, and agricultural products (containers have refrigeration units, plugged in on ship during transit). Thus an ever larger range of commodities can be shipped in containers, and the proportion of traditional "breakbulk" stevedoring work has rapidly declined.

Containerization and intermodalism have sharply reduced the cost of international shipping. Typically, for about $\$ 2,000$ a unit, forty-foot containers, each holding hundreds of televisions sets or car stereos, are shipped from Hong Kong to Los Angeles. There, the containers are stacked two-high on a container train and sent to a rail depot in Chicago. Containers then are delivered by truck directly to a store. What was once a costly and time-consuming process can now be done for a dollar or less per item and in no more than fifteen or sixteen days. With transportation costs diminished, the effective scope of international competition expands dramatically. And, of course, containerization also vastly reduces the labor needed for stevedoring operations. One gang of dockworkers, about fifteen men-crane operators, drivers of trucks or giant "straddle carriers" that move the "boxes" from crane to storage yard, men on ship unlashing the containers-unload as much cargo in ten hours as three gangs did in a week in the precontainer era. ${ }^{17}$ In West Coast ports in 1958, a longshoreman on the average loaded or unloaded 0.9 tons of cargo in one hour; in 1988, he averaged 11 tons an hour (Pacific Maritime Association, 1988).

In some ports around the world, organized dock labor has

tainerization has cut cargo loss claims, as a percentage of shipping revenues, by 60-70 percent.)

17 According to Finlay (1988: 63):

A twenty-person work unit on a container ship can remove forty to fifty containers an hour, using two cranes .... At an average weight of 15 tons per container, the hourly tonnage is 30 to 37.5 tons per worker. With a break-bulk gang, company managers estimate an average production rate of 1.5 to 2 tons per worker per hour. 
tried to block job-depleting technological changes. In Alexandria, Egypt, I was told, pneumatic grain unloading machines are used only part time, so that jobs will be preserved for dockworkers who continue to carry the grain sack by sack, and the hiring bosses can continue to rake off a share through pilferage. In Bombay, where partial decasualization and a hiring hall was established in 1948 by law (Bogaert, 1970), labor unions have insisted that the thirty-man gangs used in breakbulk work also be hired for containerships, even though only fifteen-man gangs are needed. In Genoa, a Communist local government and labor union refused for years to allow installation of container cranes; in consequence, Genoa declined drastically in significance. In Genoa's fate, however, lies a lesson: due to the efficiency of modern inland transportation systems, when productivity lagged in Genoa, containers destined for Milan were diverted to Livorno, Marseilles, or even Rotterdam, transferred to truck or train, and sped to their destination in a day or two.

This was the problem faced by dockworkers unions on the U.S. West Coast and in Rotterdam in the late 1960s, as shipping companies and terminals were investing in new containerships, cranes, docks, and storage yards. In both places, labor resistance to containerization was modest, at most. And as containerization increased efficiency, dock employment declined. In Rotterdam, despite a massive increase in tonnage handled, the number of dockworkers dropped from 17,000 in 1966 to 10,000 in 1985 . On the West Coast, where tonnage leapt from 28 million in 1960 to 135 million in 1985, the list of registered longshoremen contracted from 13,150 in 1972 to 10,187 in $1982 .{ }^{18}$

\section{B. The Quid Pro Quo: U.S. West Coast}

Why did the ILWU, with its strong coastwide control over dock labor and its ability to extort large concessions from shippers, agree to this depletion? Containerization was introduced in Oakland during the Vietnam War, when West Coast ports were bursting with shipping business. Union leaders may have underestimated its future impact (Ross, 1970: 417). More importantly, the ILWU had already made a fundamental choice in its $1960 \mathrm{M} \& \mathrm{M}$ Agreement: to abandon opposition to productivity-increasing measures in return for higher wages, pay guarantees for idle workers, and pensions. In 1972, the union agreed that container-

18 On the U.S. East and Gulf Coasts, the count of longshoremen dropped from 34,100 in 1972 to 14,100 in 1982 , even as port business grew. (In the Port of New York/New Jersey, there are now only 5,900 registered longshore workers, down from 16,000 in 1955 (De Palma, 1989).) In Great Britain, the number of registered dockworkers in the national scheme fell from an alleged 64,000 in 1947 (before decasualization began, and hence including many "casuals") to about 10,000 in 1988 (Economist, 1988). Some British dockworkers by 1988 had shifted to "nonscheme" ports. 
ization could continue, in return for a benefit-financing "tax" on increased tonnage.

The productivity gains generated by expanding container traffic financed very handsome wage and benefit increases indeed. In 1960 , the base pay rate for ILWU longshoremen was $\$ 2.82$ per hour (almost 25 percent higher than the contemporary average hourly wage in manufacturing, $\$ 2.26$ ). In 1988, the ILWU base rate ( $\$ 20.33$ per hour) was 82 percent higher than the average American hourly wage in manufacturing (\$11.18). With large premiums for evening, night, and weekend shifts, ${ }^{19}$ the average pay for ILWU members in 1988 exceeded \$58,500 (Pacific Maritime Association, 1988), at least 25 percent higher than the average, well-paid production worker in steel and automobile plants. Marine clerks averaged $\$ 74,000$, often for the kind of work done by inland clerical workers for $\$ 25,000$, and crane operators frequently made $\$ 100,000$. Total labor costs for Pacific Maritime Association employers in 1988 (including costs of the pay guarantee plan, as well as health and pension benefits) were $\$ 36$ an hour, compared to average industrial labor costs of $\$ 16$ per hour. Admission to the union-controlled list of registered dockworkers, not surprisingly, was one of the hottest tickets in town-and one usually reserved for family or close friends of current members.

Rapid productivity growth helped make these extraordinary labor costs tolerable. From 1958 to 1988, longshore wages in West Coast ports more than doubled, increasing 240 percent in constant dollars. But unit labor costs declined by 80 percent-from $\$ 16.98$ per ton in 1958 (in 1988 dollars) to $\$ 3.31$ per ton in 1988 (Pacific Maritime Association, 1988). However, this decline in unit labor costs was not as steep as the twelve-fold productivity increase over those years (growth in tons handled per man-hour). Without detailed data on the decline in prices charged for stevedoring services, it is difficult to conclude definitively that dockworkers captured a large share of those productivity increases, but that is the common view in the shipping industry and would seem to be a reasonable inference. Why have longshoremen been able to do so well, even through the $1980 \mathrm{~s}$, as workers in other U.S. industries found it difficult to maintain real wage gains and often lost ground?

The ILWU's tightly maintained coastwide collective bargaining agreement has meant that competing terminal operators, shipping companies, and their customers face roughly the same port labor costs, no matter how high. The ILWU high-wage "tariff," moreover, pales in comparison to the soaring costs shipping companies have sustained for new capital equipment-ships, cranes,

19 In 1988, the ILWU-PMA contract called for a premium of 1.3 times base pay for the second shift, and 1.7 - $\$ 34$ per hour-for the midnight shift, and double time for weekend day shifts (Pacific Maritime Association, 1988). 
landside container-handling machines, railroad cars, and the containers themselves. ${ }^{20}$ Port labor costs have declined from 75 percent to 35-40 percent of operating costs in marine terminals (Rayacich, 1986: 119). Port labor costs also constitute a smaller portion of total shipping costs. ${ }^{21}$ Hence even a 25-30 percent reduction in handling costs in U.S. container terminals, which would reduce their charges closer to Rotterdam's, would reduce total shipping costs of a transoceanic, transcontinental shipment by only about 2 percent.

Dock labor costs (along with total transportation costs) have paled, too, in relation to the total price of the high-value consumer goods that increasingly have characterized trans-Pacific trade. ${ }^{22}$ In addition, shipping firms' customers, demanding "just-in-time" deliveries to hold down inventory costs, have placed an ever higher value on speed of delivery. A shipping firm official interviewed in 1989 said, "We have 30 scheduled stack trains a week headed for points east of the Rocky Mountains on a fixed schedule. The pressures for throughput are intense. We can't afford any labor-related disruptions."

In sum, with high fixed costs and intense demand for speed and reliability in service, Pacific Maritime Association members have been unwilling to "take a strike" over compensation or control-of-hiring issues. Port authorities, fearing disruptive strikes that would undercut their reputation for speed and reliability, have been reluctant to rent terminals to nonunion operators. Waterfront employers thus have been willing to purchase continuity of operations by paying the high toll demanded by the union that controls the bottleneck of trade.

20 A new containership can cost $\$ 40$ million or more. Matson Navigation recently ordered 1,000 refrigerated containers at a cost of $\$ 26$ million. SeaLand has an inventory of 110,000 containers. Operating costs on a large containership, including interest, insurance, and depreciation, can reach $\$ 50,000$ per day. A dockside gantry crane can cost $\$ 5$ million. The big straddle carriers that move containers from yard to dockside cost $\$ 450,000$ each. Dredging, landfill, and construction of a set of container docks costs hundreds of millions-costs that are passed on to container terminal operators in rental fees.

21 A European shipping executive interviewed in 1988 estimated that at that time a forty-foot container of nuts could be shipped from Fresno, California, by rail to the U.S. East Coast and hence to Hamburg for about $\$ 2,500$. Stevedoring and port costs in the two ports (U.S. and Hamburg) would be approximately $\$ 400$, or 16 percent of total shipping costs. U.S. East Coast stevedoring charges (with the exception of New York) were roughly comparable to those of West Coast ports.

22 A port official interviewed in $\mathbf{1 9 8 9}$ estimated that to ship a forty-foot container holding 20,000 silk blouses (tagged, hanging on racks, arranged by color and size, and with a wholesale value of perhaps $\$ 200,000$ ) from Hong Kong to Macy's warehouse in New Jersey, it would cost about \$3,200. Los Angeles port charges, including transfer to an eastbound container train, would be about $\$ 230-7$ percent of the total shipping charge and about 0.1 percent of the cargo's wholesale value. 


\section{Containerization in Rotterdam: Some Differences}

In Rotterdam, most containers pass through two multiuser terminals, founded and jointly owned by consortia of competing shipping companies-ventures that might run afoul of the antitrust laws if formed in the United States. European Container Terminus (ECT) is one of the largest and most technologically sophisticated stevedoring firms in the world. From its origins in the late 1960s, ECT, like American firms, used the productivity gains of containerization to purchase labor's acquiescence in the installation of new labor-saving (and job-destroying) equipment. Unlike American firms, however, ECT refused to take any dockworkers from the central labor pool, arguing that its new container terminal was radically unlike traditional breakbulk cargo handling, requiring new full-time employees specially trained to operate expensive container-handling equipment. ECT asserted that a container terminal was more like a capital-intensive factory, which had to be operated around the clock to amortize the investment and to meet expensive containerships' demand for fast turnaround. (Traditional "breakbulk" Rotterdam dockworkers typically worked neither nights nor weekends). The Dutch unions acceded, for reasons to be noted below. ECT recruited an entirely new team of workers with whom it signed a separate collective bargaining agreement, providing for higher pay than pool workers and for full-time employment. ${ }^{23}$

At ECT, in short, the legacy of casualism was completely left behind. The productivity gains of containerized stevedoring, together with the more regular flow of ships into a multiuser terminal in an increasingly trade-intensive world, enabled ECT to provide regular pay even for slow days or slow weeks. ${ }^{24}$

But what of the workers in the shrinking breakbulk terminals and the pool? In the United States, the ILWU (like the ILA on the East and Gulf Coasts) insisted on a common deal for all longshoremen, assignment of employees from the hiring hall to container or traditional terminals alike on a rotating basis, and pension guarantees (financed by all waterfront employers, regardless

23 ECT workers were assigned on rotating basis to four (now five) shifts, but with numerous days off, so that the average work week would be thirtytwo hours. They were trained to operate a number of different machines and do different jobs, as opposed to the traditional rigid job descriptions (whereby winch operators, for example, could not be assigned to forklifts, and vice versa).

24 The basic economic logic of regular employment in busy multiuser terminals is reflected in the practices of Modern Terminals, a large stevedoring firm in Hong Kong, the world's busiest container port. In Hong Kong, wages are low (by Western standards), labor unions play an insignificant role, and governmental intervention is limited. Under these free-market conditions, Modern Terminals, like ECT, broke away from casualism, hiring men who operate its expensive cranes and yard equipment on a steady three-shift basis, paying slightly higher wages than the norm for dockworkers. Breakbulk terminals in Hong Kong continue to hire on a casual basis. 
of type) for workers rendered redundant by mechanization. ECT undertook no such obligation toward Rotterdam breakbulk dockers. In 1977, Rotterdam unions struck, demanding job preservation in the breakbulk sector. The Netherlands central government, eager to keep the port open, came to the rescue, agreeing to make an extra contribution to help provide generous pay guarantees for "temporarily unemployed" breakbulk workers and to subsidize an early retirement scheme (Peper and Van Kooten, 1983: 133; Havlicek, 1988). ${ }^{25}$

As in the United States, Dutch dock labor benefited greatly from the productivity gains generated by containerization. A young ECT forklift driver, under the 1984 wage agreement, earned approximately $\$ 22,000$ a year, working a thirty-two-hour week. An experienced container-yard heavy machine operator made $\$ 27,000$. Median pay in manufacturing, in that year, was about $\$ 22,000$, for a thirty-seven-hour week. ${ }^{26}$ Still, the proportionate gains of Dutch dockworkers are far lower than those of their American counterparts. Rotterdam dockers' wage and benefit packages were at least roughly comparable to those of workers in Dutch manufacturing firms, whereas ILWU members, as compared to average American factory workers, earned far more and had far better income security guarantees.

Moreover, the Dutch dock unions insisted on fewer efficiencydiminishing work rules. In Los Angeles and Long Beach, crane operators and "twist-lock" men (who secure containers lowered from the ship onto wheeled chassis), hold fast to a "four hours on/ four off" work rule-two men to a job, each working half a shift, but for full pay. ILWU members who worked in Rotterdam for a few weeks in 1975 observed that the pace of work there was much faster (with greater risk of injury) and that crane loads in the breakbulk sector were heavier. They felt Dutch dockworkers and union officials had a less adversarial, more cooperative relationship

25 Under the 1984 agreement, Rotterdam dockworkers could retire at age fifty-seven and receive 85 percent of their preretirement net income until they reached sixty-five, and then the general state pension (which provides approximately 60 percent of preretirement net pay). The government share of redundancy or early retirement payments outweighed the employers' share by more than three to one (Havlicek, 1988: 73-76).

26 In The Netherlands, direct payroll taxes for social programs, as well as income taxes, are much higher than those of American workers, so a Dutch dockworker's net pay was some 25 percent lower than the gross earnings mentioned above. In 1983, the Dutch marginal tax rate at the average wage level was the highest in Europe (OECD, 1987: 45). In 1988, taxes in The Netherlands soaked up 48 percent of annual gross domestic product, compared to about 30 percent in the United States (Economist, 1989a). And total industrial labor costs (wages plus employer-paid taxes and benefits) in The Netherlands were more than $\$ 15$ per hour, higher than hourly labor costs incurred by American manufacturers (Economist, 1989b). In return, Dutch workers were protected by much more generous unemployment and disability programs than the average American worker (although not than the average U.S. longshoreman) as well as by national health insurance. 
with employers (Rogers, 1979). In 1987, the typical gang working a container crane at ECT averaged ten men (crane operator, drivers of yard vehicles, men who secured above-deck containers). Gangs in Oakland then numbered eighteen, and a casual observer could note that some of them were less than essential most of the time. (In New York and Houston, to put things in a wider perspective, the ILA then insisted on twenty-two-man gangs.) In contrast to ECT's multiskilled workers and flexible task assignment schedule, the ILWU tenaciously guards rigid job demarcations (that is, a twist-lock man won't fill in as a driver if one is needed), sometimes requiring the terminal operator to send to the hiring hall for additional men before work can continue. ILWU local registration figures are tightly controlled, and shipping executives complain of the unavailability of full gangs on weekends and night shifts. Yet the ILWU insists that no work can proceed with undermanned gangs; thus costly delays are sometimes imposed on ship sailings and inland shipments.

By blocking steady employment of gangs at the same terminal, the ILWU makes it difficult for supervisors to motivate, discipline, and build on the experience of an ever changing work group. At least partly for that reason, most American container terminals "move" fewer containers per hour than does ECT (National Research Council, 1986). Stevedoring charges to shipping companies at West Coast seem to be about 25 percent higher than those in Holland. 27 Shipping company executives with cross-national experience say Rotterdam dockworkers are more careful and make fewer costly errors in storing and dispatching containers than do American longshoremen. High ILWU wage premiums for night shifts discourage twenty-four-hour operations, adding to daytime congestion at the port gates, while in Rotterdam ECT workers rotate through shifts over a multiweek cycle, evening out costs and encouraging efficient twenty-four-hour operations.

\section{Geopolitics and Competitiveness}

Shipping companies and terminals in Holland are no less capital intensive than those in the United States. They are under the same customer pressure for speed, and they are just as reluctant to "take a strike" as their American counterparts. Why haven't the Dutch dock unions, who have the same power as the ILWU to

27 Although West Coast labor costs and work rules pushed stevedoring costs per container in 1987 to $\$ 150-\$ 175$ versus $\$ 125$ in Rotterdam, until recently the situation in New York was far worse. Because of an enormous ILAnegotiated cargo assessment on each container, designed to fund pay guarantees and retirement programs for longshoremen idled by containerization, New York "box costs" in 1985 were nearly $\$ 500$ (Joseph, 1988). Even subtracting those assessments, however, Port of New York container charges, according to a Dutch official interviewed in 1987 , were still a high $\$ 290$-compared to $\$ 180$ in Charleston, South Carolina, an up-and-coming containerport where the ILA local was eager for expansion. 
strike or to slow the container crane, extracted the same extraordinary wages, benefits, and job control rules?

One factor arises from the interaction of politics and geography in shaping national boundaries and interport competition. The Netherlands is a small country. Dutch dockworkers have a nationwide cartel, to be sure, but unlike the ILWU, they do not have a geographically extensive dockwork monopoly. Their cartel can more easily be circumvented. Belgian, German, and French dockworkers, no further removed from Rotterdam than Tacoma and Long Beach are from Oakland, are not in the same union. If Dutch dockworkers push stevedoring charges too high, ships will call at Hamburg, Bremen, Antwerp, or Le Havre, from which loads can be taken to Dusseldorf almost as quickly and cheaply as from Rotterdam. European freight forwarders are keenly sensitive to labor disruption and productivity in deciding which port to use (Bird and Bland, 1988). Dutch dockworkers, therefore, must balance their demands against the threat of loss of business. ${ }^{28}$

The U.S. West Coast longshore union, in contrast, has a multiport cartel, extending from San Diego to Vancouver, Canada. Shipping firms, as members of the Pacific Maritime Association, have agreed not to establish or patronize nonunion stevedores, and the same high rates prevail in every potentially competitive West Coast port. The ILWU guards its jurisdiction fiercely and, thus far, successfully. ${ }^{29}$ Except for a few small, specialized ports in southern states, the ILA has a similar monopoly that extends from Galveston and Houston to Baltimore, New York, and Halifax, Nova Scotia. If longshore unions push stevedoring costs "too high"

28 In 1987, several stevedoring firms in Rotterdam's declining breakbulk sector, pleading mounting losses, sought to merge and dismiss about 300 workers (out of a remaining 2,200 ) in the central pool. The dockworkers union declared a highly selective strike: each day, they refused to work at only one of Rotterdam's many terminals. Union leaders were reluctant to convey the impression to the world shipping community that Rotterdam was completely shut down and unable to handle vital cargoes. The Dutch newspapers reported nervously on shipping companies that diverted ships to Bremen and published a study comparing Dutch dockworkers' pay and Rotterdam stevedoring charges with those of Antwerp. Ultimately, the strike-ending agreement to retain and gradually retire the 300 workers included a provision for a contribution by employed dockworkers to the maintenance fund.

29 In 1988, ILWU workers engaged in a work stoppage in all West Coast ports to protest a plan by an Oregon forest products company to establish a nonunion stevedoring company to load log-carrying ships. In August, 1988, San Francisco Bay longshoremen staged a one-day walkout, stalling at least ten large containerships, to protest terminal operators' plans to hire nonILWU office workers to operate computers that make dockside marine clerk jobs obsolete. A Japanese shipping line recently implemented a computer program that would enable offdock clerks in Tokyo to enter documentation that, transmitted to a computer in Los Angeles, would direct cargo transfer operations there, reducing the number of entries per container made by ILWU clerks from eighteen to two or three. The ILWU protested. A U.S. arbitrator held the change would violate job-preserving provisions in the ILWU's contract with the Los Angeles terminal operator, a subsidiary of the Japanese shipping firm (ILWU Dispatcher, 1988). 
in the United States and Canada, there are no feasible alternative ports of entry. Unlike U.S. manufacturers, who have cited low foreign wages in order to wring concessions from labor unions, American stevedores can't move their operations to low-wage foreign ports. ${ }^{30}$ The continental scope of the United States has facilitated a more impermeable dockworkers' cartel.

Similarly, in Great Britain, an island inaccessible from ports outside the recently abolished national dock labor scheme, dockworkers earned on the average $\$ 40,000$ (US) a year, far higher than the average British manufacturing worker; featherbedding was rampant, and cargo-handling costs in Southhampton were double those in Rotterdam (Carding, 1989; Economist, 1988: 51-52). On the island continent of Australia, too, a nationwide union-dominated dock labor scheme (Fadem, 1967) has led a level of obstructionism and unreliability that makes the ILWU look like a paragon of efficiency. ${ }^{31}$

\section{E. Labor Law}

Besides Rotterdam's greater vulnerability to competition, differences between American and Dutch labor law help explain why Rotterdam dockworkers' pay is more moderate and Dutch stevedoring operations are more efficient. American labor law motivates American unions to employ confrontational tactics to seek special benefits and job-protecting work rules for their particular trades. Dutch labor law encourages a less individualistic and adversarial approach, attuned to the longer-run interests of workers in the nation as a whole.

Consider, for example, Dutch dock unions' acquiescence when ECT negotiated a separate agreement with workers hired from outside the labor pool, providing for permanent employment, higher pay, and more flexible job assignment rules. The ILWU (or the ILA) assuredly would have struck any terminal that attempted such a change. That is why, despite the widely admired efficiency of the ECT labor-relations model (National Research Council, 1986), no American equivalent has been established.

The Dutch unions' acquiescence stems from the structure of the Dutch labor relations system, which was pushed by years of price and wage controls and a tradition of corporatism (Lijphart, 1975) toward relatively centralized national collective bargaining

30 An Ohio steel mill can lose business to a Korean mill. But a container of Korean goods destined for Cleveland cannot be offloaded in Seoul. And it matters not to ILWU members in Oakland that Hong Kong dockworkers are paid only $\$ 6,000$ (US) a year.

31 An Australian container-line executive recently stated, "We load our ships in the U.S. in 48 hours, but in Australia it takes about eight days." Another said that Australian dock labor problems make it impossible to operate the kind of weekly fixed-sailing-time service common in other trans-Pacific trades (Cole, 1989). 
(Flanagan et al., 1983).32 When asked about ECT's separate peace, officials of the largest Dutch labor union federation, the FNV, expressed indifference about which trade union assumed jurisdiction of container terminal work, as long as the company dealt with a branch of the FNV. Union officials saw containerization as a route to the expansion of trade as a whole and hence to the expansion of national employment.

In addition, Dutch law, along with the tradition of nationallevel collective bargaining, virtually ensures that wages or benefits secured at one worksite in an industry will be extended, by agreement or by government order, to all firms in the industry. Regardless of the number of workers in a firm who pay union dues, there are essentially no nonunion companies that compete by paying markedly lower salaries or benefits than the national norm (although they can compete for workers by offering more). In a Dutch stevedoring firm, to make the comparison clear, individual workers might join one of several competing nationally organized labor unions or none at all. No union election is held at the individual worksite, and no contract is negotiated there. Federations of unions jointly bargain with federations of employers concerning the entire transport sector. The individual employer, therefore, has relatively little stake in "keeping the union out" of his establishment. Although only 37 percent of Dutch workers were duespaying union members in 1984 (compared to about 18 percent in the United States), probably more than 70 percent were covered by collective bargaining agreements (see Freeman, 1988; Thomson, 1981: 305). In this legal structure, the labor-management struggle for advantage occurs primarily not at the firm level but at the nationwide industry level. The union federations strive for rough equality across industries. Individual union branches, therefore, such as Rotterdam dock workers' unions, are in some degree discouraged from seeking special benefits for their own members.

Moreover, many of the most important worker benefitsthose relating to job security and safety and income replacementare sought and achieved not by bargaining but by legislation. Even when in the minority, the Dutch Labor and Socialist political parties, more closely linked to the trade union movement than the U.S. Democratic party, play a strong role in the coalition-based parliamentary politics that characterizes The Netherlands. Dutch law requires employers to seek agency approval to fire a worker, to prove "just cause" in contested cases, and to pay termination

32 Scholars typically measure union centralization in terms of the level at which bargaining is conducted (national, regional, the local plant); the degree of control central federations exert over local union strike activities and finances; and the absolute number of union organizations (Wilensky, 1976; Cameron, 1984). Merging various studies, on a scale of 0 (least centralized) to 7, The Netherlands has been ranked 5.7, second in Europe only to Austria (7.0). Sweden was scored 5.5 and the United States a very decentralized 0 (Wallerstein, 1985: 42). This footnote is paraphrased from Rogers (1990). 
benefits according to a statutory schedule keyed to years of employment (Knegt, 1989). All workplaces with at least one hundred employees (including marine terminals) are obligated by statute to have a worker-elected works council (ondernemingsrad); employers must notify and consult with the council concerning significant planned charges affecting work or employment levels (Van Esveld and Van Aerde, 1978). National legislation, applicable to all employees in The Netherlands, specifies generous rights to paid holidays, vacations, disability payments, sick days, and basic health care insurance. Dutch law provides for a high minimum wagemuch higher, as compared to average wages, than the U.S. minimum wage (OECD, 1987: 43)-and unemployment benefits that are much higher (in relation to the unemployed worker's previous earnings) and longer-lasting than those provided by U.S. laws. ${ }^{33}$ All this means that for the Rotterdam dockworker, hopes for security do not ride solely, or even primarily, on the demands made by his local union.

American labor law, in contrast, provides relatively little in the way of statutorily guaranteed job security, vacation, health care, and unemployment benefits. No peak associations (such as the AFL-CIO and the National Association of Manufacturers) negotiate sectorwide collective agreements. Under the National Labor Relations Act, power flows to the local union that manages to win an election in a particular worksite. The benefits a union negotiates with any individual employer or group of employers are not extendable by law (as in The Netherlands, or as would have been the case under the defunct 1933 NIRA) to competitor firms in which the union has less strength.

The American legal structure thus puts each union "on its own," with little help to be expected in winning benefits and protections for its members from the government or from an overarching federation of labor unions. Each union has an incentive to seek a closed shop (or its legal equivalent) in particular firms or industries and use it to extract maximum pay and job security advantages (including makework rules). Thus when an American labor union leader, in the ILWU or elsewhere, hears of plans for a technological or organizational innovation, he thinks, "Will it eliminate jobs in my union?" The Dutch union leader, linked in a tight confederation including many industries, thinks "Will it increase competitiveness and create (or help preserve) jobs in the country as a whole?"

By encouraging job-protecting or self-seeking behavior on the part of individual, company-based local unions, the American legal structure also encourages nonunion firms to resist unionization. In

33 In The Netherlands, workers who are laid off are entitled to unemployment payments equaling 70 percent of their gross monthly pay for six months, followed by 60 percent of gross pay for two years (Havlicek, 1988: 7376). 
consequence, and in contrast to The Netherlands, differences in pay and work rules across American firms in the same industry (unionized versus nonunion) quite often are large, as are differences across industries with different unions. Hence American unions, unlike their Dutch counterparts, invest enormous efforts (with declining rates of success) in contested workplace elections, endless legal appeals concerning the conduct of elections (Flanagan, 1987), and jurisdictional disputes among unions (Bok, 1971).

It was in this competitive and conflict-encouraging legal context that the ILWU has bargained, seeking maximum benefits and job protections for its own members in return for acceding to containerization and nondisruption of the flow of goods through the port. Unlike Dutch national-level union leaders, the ILWU has little incentive to accept work rules that by improving transport efficiency would maximize employment for workers in the nation as a whole. ${ }^{34}$

\section{v. CONCLUSION}

To stabilize port labor relations, the Dutch and American governments both helped create legally enforceable, competition-restricting cartels (in Rotterdam in 1916, on the Pacific Coast in 1934). Access to dockwork was restricted to a limited circle of registered workers. Dock unions, in consequence, gained strength. Workers attained greater stability of earnings and more control over on-the-job work rules. In neither country, however, did dock unions block the dramatic increases in productivity (and decline in demand for dock labor) made possible by containerization and intermodal transport systems. Rather, in return for uninterrupted and efficient cargo handling, they accepted guarantees of high wages and regular pay (regardless of fluctuations in the need for dock labor).

Despite these commonalities, economic outcomes in the two countries vary. American longshoremen have retained hiring practices and work rules that make U.S. stevedoring operations less efficient and more costly to shippers than comparable operations in Rotterdam. Compared to the average worker in their respective nations, American longshoremen earn much more money, Dutch dockworkers only slightly more.

In accounting for these differences, perhaps cultural differences may play some role, inclining the Dutch toward cooperation,

34 For an extended analysis of how the National Labor Relations Act contributes to the low union density and decentralization of the American labor movement, see Rogers (1990). Rogers shows how unions in low union-density and/or decentralized union countries have an incentive to strive for self-seeking redistributive benefits, while unions in high-density, centralized systems, such as The Netherlands, have greater incentives to pursue "collective gain" strategies, moderating today's demand to the extent it appears to promote economic benefits tomorrow for the labor movement as a whole. 
and individualistic Americans toward conflict. ${ }^{35}$ But differences in law are clearer and more clearly important. Dutch law tends to concentrate power in national-level unions, to narrow wage differentials among workers in different industries, and to guarantee dockworkers-and other workers-high levels of income replacement in case of unemployment or underemployment. At least partly in consequence of these quality- and security-enhancing measures, Dutch labor leaders have been inclined to seek relatively uniform benefits for all workers in The Netherlands. Rotterdam dockworkers have not been passive. Through strikes, they have sought to preserve jobs for technologically redundant workers. But Dutch dockworkers' unions, more strongly backed than their American counterparts by security-enhancing laws, have been more willing than American longshoremen to yield to management with respect to hiring and work-assignment practices.

American labor law, in contrast, establishes a decentralized, adversarial method of empowering labor unions and vests more power and responsibility in local unions (Bok, 1971). One consequence is more decentralized bargaining than one finds in Holland, and much larger differences in pay and benefits among workers. American labor law, moreover, provides workers less legal protection against dismissal, as well as much lower governmentally guaranteed unemployment and retirement benefits. American longshore unions, less bolstered by government-mandated protections, less constrained by nationwide pay norms, understandably have been more avidly self-interested than their Dutch counterparts, using work rules to create extra jobs, extracting extraordinary benefits for their own dwindling membership, and refusing to relinquish job control to conform to new port technologies.

In this regard, the motives of ILWU leaders, and of their ILA brethren on the East and Gulf Coasts, reflect the structure of American labor law. But legally inspired motivation only partly accounts for the difference in outcomes. At least in the $1980 \mathrm{~s}$, other American labor unions, while presumably no less self-seeking than the ILWU, have been more cooperative in many respects, relaxing inefficient work rules and restraining demands for higher wages and benefits. The ILWU's special advantage in fulfilling its aims stems from its unique invulnerability to foreign competition. This immunity rests on three pillars: the immobility of port work (as contrasted to manufacturing); the large geographical scale of the United States; and the declining importance of stevedoring costs in relation to total transportation costs and the demand for uninterrupted service. Standing on these pillars, the ILWU has been able to extend its cartel over all potentially competing ports,

35 Despite similarities with American labor law structures in Japan and in Canada, Japanese and Canadian workers and unions behave differently from their American counterparts, at least partly, it has been argued, for cultural reasons (Lipset, 1986; Waldron, 1985). 
and shipping companies and their customers have been willing to pay the ILWU's high tolls.

Located in a smaller, more trade-dependent country, Dutch dockworkers lack one crucial pillar-the ability to extend their cartel to all competing ports. As market-driven technological innovations in transportation have eroded the natural monopolies enjoyed by well-located seaports, Rotterdam has become vulnerable to competition from other Northern European ports. Dutch dock unions, in turn, have had to become sensitive to the comparative efficiency of Rotterdam port terminals. Dutch labor law, too, has been responsive to foreign competition. In recent years, The Netherlands, faced with high unemployment and slow economic growth, has scaled back some of its generous statutory employee benefits, which seem to discourage employers from expanding and hiring new workers.

In sum, intensifying competition has imposed restraint on both Dutch labor and most American labor unions. National labor law structures may encourage different initial dispositions-in the United States toward union-specific job protection measures and benefits, in The Netherlands toward uniform nationwide benefits and job growth. But even more important in shaping outcomes, it appears, are the economic imperatives generated by an increasingly integrated global economy. When competitive necessity knocks, many domestically created legal entitlements crumble.

This does not mean that international competition will inevitably displace all national laws that bolster economic security or protect pockets of economic inefficiency. As in the case of the ILWU, under some conditions an economic sector may be able to afford generous or even clearly inefficient security arrangements and still thrive. A unified European Economic Community might enact coordinated social benefit and labor laws that would entrench and extend Northern European welfare state standards. Conceivably, Dutch dockworkers could merge with other European dock unions, establishing a continent-wide cartel that not only would protect current benefits but even would extract American-style dock wages and work restrictions. Cooperation at the EEC level, one might note, has yielded enormous, economically inefficient subsidies for European farmers, along with protectionist policies.

In general, however, the opposite trend seems more probable. International competition has been poking holes in legally protected worker and producer cartels, chipping away at unusually generous subsidies and statutory benefits. Under Prime Minister Thatcher, the British government, concerned about the U.K.'s declining competitiveness, passed legislation discouraging the strikes that had crippled British industry and, more recently, completely abolishing the 1946 Dock Labour Scheme. In 1984, the Italian government installed new management in the Port of Genoa, cut the 
size of container gangs in half, and installed a pay incentive plan based on productivity. ${ }^{36}$ As newly containerized terminals in Charleston, Norfolk, and Halifax convinced longshore locals to increase productivity, the New York longshore union, suffering from a continuing loss of port work, agreed to reduce its "cargo assessment" on containers by 50 percent (Joseph, 1988: 10b; Boyes, 1989). The U.S. Federal Maritime Commission outlawed an inefficient job-creating work rule long defended as sacred by the East Coast longshore union. ${ }^{37}$

These developments provide support for at least one aspect of the "competitive convergence" hypothesis: as international competition increases, domestic political pressures mount against national laws that bolster glaringly inefficient labor practices, regulatory protections, and subsidies. To repeat an earlier qualification: all countries need not be inexorably driven toward the weak unions and minimal welfare rights provided in Hong Kong or Taiwan. Organized labor and labor-oriented political parties will remain stronger in some countries than in others. Some legal traditions are hard to change. And some job security and welfare protections undoubtedly contribute to economic efficiency. Moreover, political pressures may arise for internationally coordinated labor law (even beyond the EEC), ${ }^{38}$ just as they have for interna-

36 Labor reform in Genoa did not come easily. Strikes crippled the port for most of 1987 . The government had to give 900 laid-off dockworkers lumpsum bonuses averaging $\$ 60,000$. The dock labor union was given a 24 percent share in the container terminal company (Vail, 1988). Still, a great many container loads originating in Northern Italy are shipped not from Genoa but from La Spezia, a private port where the dockworkers' organization does not control the workforce, or from non-Italian ports (Containerization International, 1989).

Similar governmental efforts to reduce overmanning and promote efficiency by weakening dock union power or changing work arrangements have been undertaken recently in Spain (O'Byrne, 1987; Champion, 1989), Portugal (Dansie, 1989), and Australia (Mundford, 1989).

37 The ILA's "fifty-mile agreement," dating from 1967, concerning the loading and unloading of less-than-full-load containers, in which packages from different shippers or for different consignees were consolidated. The ILA had insisted that this "stuffing and stripping," if done within fifty miles of the port, must be done only by ILA members-in effect, at ILA-manned pierside warehouses. This, the FMC held, violated the federal Shipping Act's prohibition against discrimination against freight forwarders and non-ILA warehousemen. A customs broker testified that when imported containers were stripped off the pier by nonunion warehouses, there had been a material reduction in damage and pilferage, fewer delays, misdeliveries, and shortages (Federal Maritime Commission, 50 Mile Container Rules Case, Docket 81-11, Initial Decision of Administrative Law Judge, February, 1985). On the West Coast, the ILWU agreed to create a new job classification-"terminal warehouseman"-paid at lower hourly rates than longshoremen, in order to stanch the flow of container stuffing/stripping warehouses to inland locations (Levy, 1988: 19). And the Vancouver, Canada, local, feeling competition from other ports, abandoned its own "eighty-mile" rule (Cargo Systems, 1989). Recently, some ILWU locals have agreed to assign additional steedymen to specific stevedoring firms for certain complex jobs.

38 Conceivably, as fewer American workers in the country as a whole receive labor union protection, political pressures will eventually grow for uni- 
tionally coordinated regulations to deal with costly problems such as curtailing emissions that contribute to acid rain, phasing out chlorofluorocarbons, and controlling pollution of coastal waters.

Convergence, in short, may not be complete and need not descend to the lowest common denominator; it can occur at various points on the security-to-efficiency continuum. The point is that legal rules, agreements, and institutions that produce very large competitive inefficiencies are more and more likely to come under strong attack. American longshoremen, sheltered by an unusual invulnerability to competition, provide the exception that helps prove the rule-and one wonders how long that will last, as American ports compete for trade and American exporters search for ways to reduce their costs. In the realm of business regulation, labor, and perhaps even tort, taxation, and welfare law, national differences in law among industrialized nations seem likely to shrink and hence to matter less and less. In the political struggle between security and efficiency, the advocates of efficiency may not prevail, but they probably will have an increasingly powerful say, pushing legal systems toward roughly convergent economic outcomes.

\section{REFERENCES}

BADARACCO, Joseph (1985) Loading the Dice: A Five Country Study of Vinyl Chloride Regulation. Boston: Harvard Business School Press.

BALL, Joseph H. (1966) The Government-subsidized Union Monopoly: A Study of Labor Practices in the Shipping Industry. Washington, D.C.: Labor Policy Association.

BAYLEY, David (1976) Forces of Order: Police Behavior in Japan and the United States. Berkeley: University of California Press.

BELL, Daniel (1964) "The Racket-ridden Longshoremen: The Web of Economics and Politics" in Daniel Bell, The End of Ideology. New York: Free Press.

BIRD, James, and Gail BLAND (1988) "Freight Forwarders Speak: The Perception of Route Competition via Seaports in the European Communities Research Project, Part 1," 15 Maritime Policy and Management 35.

BOGAERT, Michael (1970) Trade Unionism in Indian Ports: A Case Study at Calcutta and Bombay. New Delhi: Shri Ram Centre for Industrial Relations.

BOK, Derek C. (1971) "Reflections on the Distinctive Character of American Labor Law," 84 Harvard Law Review 1394.

BOYES, Jane R.C. (1989) "New York Strives for a Comeback," Containerization International 5 (July).

BRAITHWAITE, John (1985) To Punish or Persuade: Enforcement of Coal Mine Safety. Albany, NY: SUNY Press.

BRICKMAN, Ronald, Sheila JASANOFF, and Thomas ILGEN (1985) Controlling Chemicals: The Politics of Regulation in Europe and the United States. Ithaca, NY: Cornell University Press.

CAMERON, David R. (1984) "Social Democracy, Corporatism, Labor Quiescence, and the Representation of Economic Interests in Advanced Capitalist Society" in J. Goldthorpe, ed., Order and Conflict in Contemporary Capitalism. New York: Oxford University Press.

versal, legally guaranteed employee health care and income-replacement policies along the lines of European welfare states. 
CAMPBELL, Scott (1986) Transformation of the San Francisco Bay Area Shipping Industry and Its Regional Impacts. Berkeley, CA: Institute of Urban and Regional Development.

CARDING, Tony (1989) "Costs Cripple British Ports," Container News, 12 (September).

CARGO SYSTEMS (1989) "Slicing the Intermodal Lake," Cargo Systems, 39 (March).

CHAMPION, Vincent (1989) "Spanish Ports Travel a Difficult Road," Cargo Systems, 30 (January).

CH'EN Kang (1977) "Changes at the Shanghai Harbor Docks," in Stephen Andors, ed., Workers and Workplaces in Revolutionary China. White Plains, NY: Sharpe.

COLE, Susan K. (1989) "U.S./Australian Trade a Difficult Proposition for Many Ocean Carriers,” Pacific Shipper 6-7 (September 4).

CONTAINERISATION INTERNATIONAL (1989) "Italian Labour Reforms Aim to Revitalize Major Ports," Containersation International, Special Supplement, p. viii.

COOPER, Frederick (1987) On the African Waterfront: Urban Disorder and the Transformation of Work in Colonial Mombasa. New Haven, CT: Yale University Press.

DANSIE, Janet (1989) "Look Out for the Port Side," Cargo Systems, 63 (May).

DAY, Patricia, and Rudolf KLEIN (1987) "The Regulation of Nursing Homes: A Comparative Perspective," 65 Milbank Quarterly 303.

DE PALMA, Anthony (1989) "Longshore Hiring Shape Ends in New York Harbor," New York Times p. A-6 (June 6).

ECONOMIST (1988) "Dock-Labour Scheme: Quaint Seaside Customs," Economist, 51-52 (July 2).

(1989a) "Tax Burden," Economist 105 (September 30). (1989b) "Labour Costs," Economist 81 (August 6).

FADEM, Joel (1967) "The Case of the Australian Waterfront: Organizational Design," Journal of Industrial Relations, 26 (March).

FAIRLEY, Lincoln (1979) Facing Mechanization: The West Coast Longshore Plan. Los Angeles: Institute of Industrial Relations, University of California at Los Angeles.

FINLAY, William (1988) Work on the Waterfront: Worker Power and Technological Change in a West Coast Port. Philadelphia: Temple University Press.

FLANAGAN, Robert J. (1987) Labor Relations and the Litigation Explosion. Washington, DC: Brookings Institution.

FLANAGAN, Robert J., David SOSKICE, and Lloyd ULMAN (1983) Unionism, Economic Stabilization, and Incomes Policies: European Experience. Washington, DC: Brookings Institution.

FREEMAN, Richard B. (1988) "Labor Market Institutions and Economic Performance," 3 Economic Policy 64.

FREEMAN, Richard B., and James L. MEDOFF (1984) What Do Unions Do? New York: Basic Books.

GALANTER, Marc (1983) "Reading the Landscape of Disputes: What We Know and Don't Know (and Think We Know) About Our Allegedly Contentious and Litigious Society," 31 U.C.L.A. Law Review 4

HARTMAN, Paul T. (1969) Collective Bargaining and Productivity: The Longshore Mechanization Agreement. Berkeley: University of California Press.

HAVLICEK, Dieter (1988) Experience with Labor Redundancy Schemes in the Transport Sector in Western Europe, the United States, and Japan. Washington, DC: World Bank.

HAWLEY, Ellis W. (1966) The New Deal and The Problem of Monopoly. Princeton, NJ: Princeton University Press.

HOBSBAWM, E. J. (1964) Labouring Men: Studies in the History of Labour. London: Weidenfeld \& Nicolson.

ILWU DISPATCHER (1988) "Computer Jurisdiction Protected," ILWU Dispatchers 1, 3 (December 13).

JASANOFF, Sheila (1986) Risk Management and Political Culture. New York: Russell Sage Foundation.

JENSEN, Vernon (1964) The Hiring of Dockworkers and Employment Prac- 
tices in the Ports of New York, Liverpool, London, Rotterdam and Marseilles. Cambridge, MA: Harvard University Press.

- (1974) Strife on the Waterfront: The Port of New York Since 1945. Ithaca, NY: Cornell University Press.

JOSEPH, Gloria (1988) "Box-moving Costs Vary Widely at Top 3 North Atlantic Ports," Journal of Commerce, 10B (July 28).

KAGAN, Robert A. (1988) "What Makes Uncle Sammy Sue?" 21 Law \& Society Review 717.

(1989) "Understanding Regulatory Enforcement," 11 Law \& Policy 89.

KELMAN, Steven (1981) Regulating America, Regulating Sweden: A Comparative Study of Occupational Safety and Health Policy. Cambridge, MA: MIT Press.

KERR, Clark, and Lloyd FISHER (1949) "Conflict on the Waterfront," Atlantic Monthly 17 (September).

KERR, Clark, and Abraham SIEGEL (1964) "The Interindustry Propensity to Strike-An International Comparison," in Clark Kerr, ed., Labor and Management in Industrial Society. Garden City, NY: Doubleday.

KIMELDORF, Howard (198) Reds or Rackets? The Making of Radical and Conservative Unions on the Waterfront. Berkeley: University of California Press.

KIRP, David L. (1982) "Professionalization as a Policy Choice: British Special Education in Comparative Perspective," 34 World Politics 137.

- (1979) Doing Good by Doing Little: Race and Schooling in Britain. Berkeley: University of California Press.

KNEGT, Robert (1989) "Regulating Dismissal from Employment: Administrative and Judicial Procedures in The Netherlands," 11 Law \& Policy 175.

KUTLER, Stanley I. (1982) The American Inquisition: Justice and Injustice in the Cold War. New York: Hill \& Wang.

LANGBEIN, John H. (1985) "The German Advantage in Civil Procedure," 52 University of Chicago Law Review 823.

LARROWE, Charles P. (1955) Shape-up and Hiring Hall: $A$ Comparison of Hiring Methods and Labor Relations on the New York and Seattle Waterfronts. Berkeley: University of California Press.

(1972) Harry Bridges: The Rise and Fall of Radical Labor in the United States. Westport, CT: Lawrence Hill \& Co.

LEVENBACH, M. G. (1964) "Sociaal Bestuur," in Nederlands Bestuursrecht III. Samson: Alphen aan den Rijn.

LEVY, Robert D. (1988) "The Relation of U.S. West Coast Port Authorities to Longshore Labor and the Multi-Employer Bargaining Group." M.A. Thesis, University of Washington.

LIJPHART, Arend (1975) The Politics of Accommodation: Pluralism and Democracy in The Netherlands. 2d ed. Berkeley: University of California Press.

LIPSET, Seymour Martin (1986) "North American Labor Movements: A Comparative Perspective," in S. M. Lipset (ed.), Unions in Transition. San Francisco: Institute of Contemporary Studies.

LIS, Catherina (1986) Social Change and the Labouring Poor: Antwerp, 1770-1860. New Haven, CT: Yale University Press.

LUNDQVIST, Lennart J. (1980) The Hare and The Tortoise: Clean Air Policies in the United States and Sweden. Ann Arbor: University of Michigan Press.

MILLER, Raymond C. (1969) "The Dockworker Subculture and Some Problems in Cross-cultural and Cross-Time Generalizations," 11 Comparative Studies in Society \& History 302.

MNOOKIN, Robert H., and Lewis KORNHAUSER (1979) "Bargaining in the Shadow of the Law: The Case of Divorce," 88 Yale Law Journal 950.

MORRIS, R. (1983) "The Melbourne Dockers War," 10 Maritime Policy \& Management 53.

MUNDFORD, Chris (1989) "Australian Port Strategy: Enterprise Initiative," Cargo Systems 51 (June).

NATIONAL RESEARCH COUNCIL (1986) Improving Productivity in U.S. Marine Container Terminals. Washington, DC: National Academy Press.

NIJHOF, Erik (1988) "Grezien de Dreigende Onrust in De Haven . . " ": De Ontwikkelung van de Arbeidsverhoudingen in de Rotterdamse Haven, 
1945-1965 ("In Light of the Threat of Unrest in the Port . . ": The Development of Industrial Relations in the Port of Rotterdam, 1945-65). Amsterdam: Stichting beheer IISG.

NIJHOF, Erik, and Peter SCHRAGE (1988) "Behind the Picketline: The Home Front of the Rotterdam Dockers in Times of Social Warfare, 1900-1980," in L. Heerma van Voss \& H. Diederiks (eds.), Industrial Conflict: Papers Presented to the Fourth British-Dutch Conference on Labour History. Amsterdam: Stichting beheer IISG.

NORTHRUP, Herbert R. (1942) "The New Orleans Longshoremen," 57 Political Science Quarterly 526.

O'BYRNE, Leo (1987) "Spain: Port Development," Cargo Systems, 37 (December)

OECD (1987) OECD Economic Surveys: Netherlands. Paris: Organization for Economic Cooperation and Development.

(1986) OECD Economic Surveys: Netherlands. Paris: Organization for Economic Cooperation and Development.

PACIFIC MARITIME ASSOCIATION (1988) Annual Report. San Francisco: Pacific Maritime Association.

PELS, P. S. (1957) "The Development of Collective Employment Agreements in The Netherlands" in A. Sturmthal (ed.), Contemporary Collective Bargaining in Seven Countries. Ithaca, NY: Institute of International Industrial and Labor Relations, Cornell University.

PEPER, Bram, and Gerrit VAN KOOTEN (1983) "The Netherlands: From an Ordered Harmonic to a Bargaining Relationship," in Solomon Barkin (ed.), Worker Militancy and Its Consequences: The Changing Climate of Western Industrial Relations. 2d ed. New York: Praeger.

PHILLIPS, Gordon, and Noel WHITESIDE (1985) Casual Labor: The Unemployment Question in the Port Transport Industry, 1880-1970. New York: Oxford University Press.

QUAM, Lois, Robert DINGWALL, and Paul FENN (1987) "Medical Malpractice in Perspective," 294 British Medical Journal 1529-31; 1597-1600.

RAYACICH, Daniel (1986) "Marine Terminal Operations in the United State," in National Research Council, Improving Productivity in U.S. Marine Container Terminals. Washington, DC: National Academy Press.

ROGERS, Joel (1990) "Divide and Conquer: Further 'Reflections on the Distinctive Character of American Labor Laws,'" 1990 Wisconsin Law Review (in press).

ROGERS, Sidney (1979) "Six Longshoremen in Rotterdam," in Robert Schrank (ed.), American Workers Abroad. Cambridge, MA: MIT Press.

ROSS, Philip (1970) "Waterfront Labor Response to Technological Change: A Tale of Two Unions," 21 Labor Law Journal 397.

SCHNEIDER, Betty, and Abraham SIEGEL (1956) Industrial Relations in the Pacific Coast Longshore Industry. Berkeley: Institute of Industrial Relations, University of California.

SCHUMPETER, Joseph (1942) Capitalism, Socialism and Democracy. New York: Harper.

STURMTHAL, Adolf (1957) "An Essay on Comparative Collective Bargaining" in A. Sturmthal (ed.), Contemporary Collective Bargaining in Seven Countries. Ithaca, NY: Institute of International Industrial and Labor Relations, Cornell University.

THOMSON, A. (1981) "A View From Abroad," in J. Stieber, R. B. McKersie, and D. Q. Mills (eds.), U.S. Industrial Relations, 1950-1980. Madison, WI: Industrial Relations Research Association.

VAIL, Bruce (1988) "Genoa Pushes to Reclaim Status in Med," American Shipper 48 (April).

VAN ESVELD, N. E. H. and J. A. O. M. VAN AERDE (1978) "Labour Law," in Netherlands Comparative Law Association, Introduction to Dutch Law for Foreign Lawyers. Deventer, The Netherlands: Kluwer.

VAN VOORDEN, William (1984) "Employers Associations in The Netherlands" in John P. Windmuller and Alan Gladstone (eds.), Employers Associations and Industrial Relations: A Comparative Study. Oxford: Clarendon Press.

VOGEL, David (1986) National Styles of Regulation: Environmental Policy in 
Great Britain and the United States. Ithaca, NY: Cornell University Press.

WALDRON, Arthur (1985) "Japan: The Legal Roots of Labor Peace," Public Interest 421 (Summer).

WALLERSTEIN, M. (1985) "Working Class Solidarity and Rational Behavior." Ph.D. Dissertation, University of Chicago.

WILENSKY, Harold (1976) The "New Corporatism," Centralization, and the Welfare State. Beverly Hills, CA: Sage Publications.

\section{CASE CITED}

Schechter Poultry v. United States, 294 U.S. 495 (1935).

\section{STATUTE CITED}

National Labor Relations Act, 29 U.S.C. $\S \S 151-168$ (1935). 
HeinOnline -- 24 Law \& Soc'y Rev. 701990 